\title{
Cost and Return Estimates of a Mamey Sapote Grove in South Florida, 2017
}

\author{
Fredy H. Ballen, Aditya Singh, Edward A. Evans, and Jonathan Crane ${ }^{2}$
}

\section{Introduction}

Mamey sapote (Pouteria sapota), originally from Mexico and Central America, is a tropical fruit tree cultivated in Central America, South America, and the Caribbean. It can be grown in subtropical conditions, but it is sensitive to freezing temperatures. The fruit was first reported in Florida by Pliny Reasoner in 1887. After several introductions from the Caribbean during the early twentieth century and an influx of Cuban Americans to Florida, a small but vibrant mamey sapote industry began in the mid-1970s in south Florida (Morton 1987; Pantin 1991). Commercial production of mamey sapote in the United States is limited to south Florida, mainly Miami-Dade County. The United States also imports a limited amount of fruit from Puerto Rico, with the main destination being the Boston market.

The 'Magaña' and 'Pantin' cultivars make up 95\% of the total area cultivated (about 500 acres) in south Florida (Figures 2 and 3 ). An established orchard (7 years and older) may yield up to 18,000 to 22,000 pounds of fruit per acre (Goenaga and Jenkins 2012), but after considering biannual fluctuations in crop yield, annual average yield is usually about 9,000 pounds per acre. The average Homestead free on board price (F.O.B.) in 2016 was $\$ 1.17$ per pound (the F.O.B. price is the final price yielded to the growers after meeting all the supply side costs). Hence, the crop is worth upwards of $\$ 5.2$ million at the farm gate level.

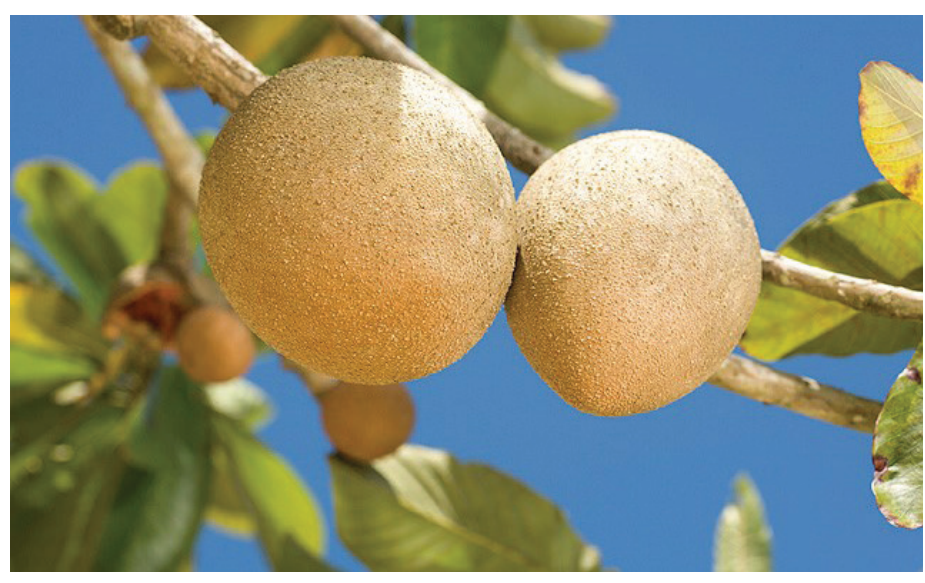

Figure 1. Mamey sapote. Credits: USDA

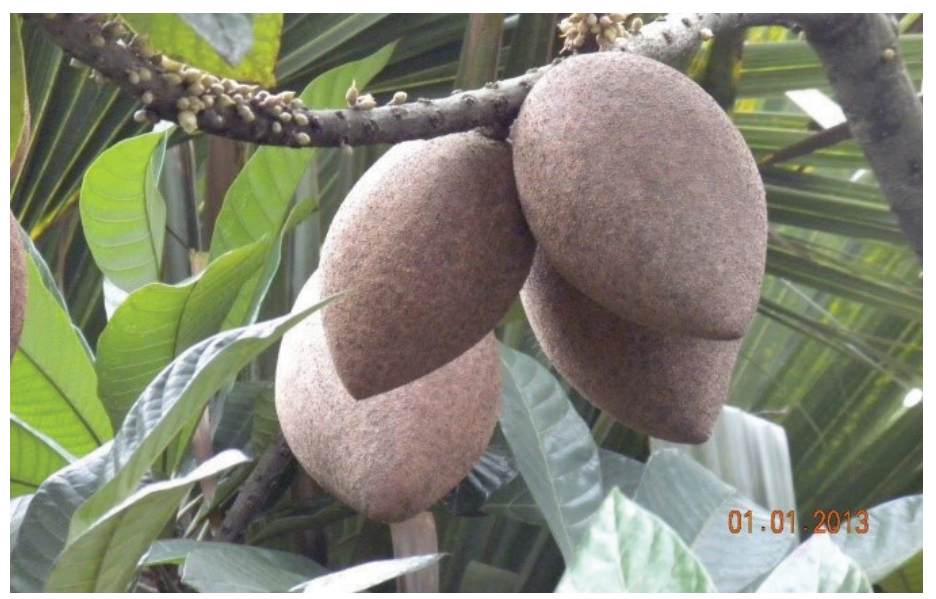

Figure 2. 'Magaña' cultivar.

Credits: Jonathan Crane, UF/IFAS

1. This document is FE1039, one of a series of the Food and Resource Economics Department, UF/IFAS Extension. Original publication date February 2018. Visit the EDIS website at http://edis.ifas.ufl.edu.

2. Fredy H. Ballen, economic analysis coordinator II; Aditya Singh, research scholar; Edward A. Evans, interim center director and professor, Food and Resource Economics Department, and Jonathan H. Crane, tropical fruit crop specialist, UF/IFAS Tropical Research and Education Center, Homestead, FL.

The Institute of Food and Agricultural Sciences (IFAS) is an Equal Opportunity Institution authorized to provide research, educational information and other services only to individuals and institutions that function with non-discrimination with respect to race, creed, color, religion, age, disability, sex, sexual orientation, marital status, national origin, political opinions or affiliations. For more information on obtaining other UF/IFAS Extension publications, contact your county's UF/IFAS Extension office. 


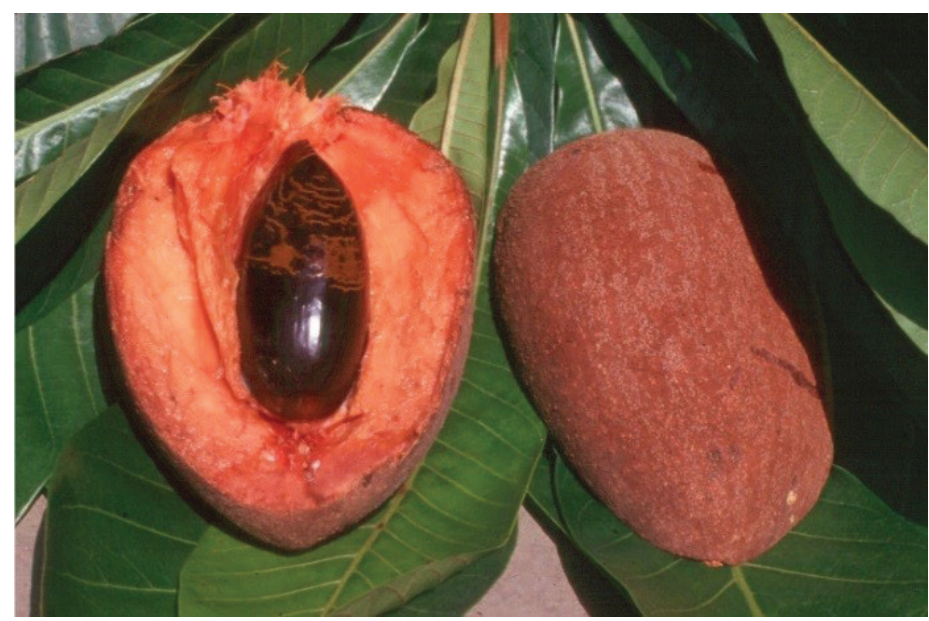

Figure 3. 'Pantin' cultivar.

Credits: Jonathan Crane, UF/IFAS

There is little information on the production costs and returns of minor tropical fruit crops, so our objective is to provide an estimate of the costs and returns associated with an established mamey sapote orchard in south Florida. Our information was obtained from field interviews with industry experts and with growers cultivating the fruit in small acreages (1-3 acres) in south Florida. The information presented reflects a wide variety of production practices, and it is intended only as a guide to estimate the financial requirements of maintaining a mamey sapote grove. Readers interested in specific information about the cultural practices of mamey sapote may wish to peruse FC30, Mamey Sapote Growing in the Florida Home Landscape by Balderi et al. (2008) (http://edis.ifas.ufl.edu/mg331).

\section{Main Assumptions}

Most of the growers in south Florida already own the land, so a rental cost of $\$ 550$ per acre per year is used in this analysis to reflect the opportunity cost of land. The budget and production cost items are based on a one-acre orchard on a per-year basis. Given the wide diversity of cultural practices and managerial styles among the growers interviewed, we report average costs and prices for the present analysis.

\section{Orchard Layout}

In south Florida, mamey sapote plantings are typically spaced 25 to 30 feet between-rows and 15 to 20 feet in-rows (between trees), resulting in a planting density of 75 to 145 trees per acre (Mossler and Crane 2013). For this analysis, we consider a density of 116 ( $25 \times 15$ spacing) trees per acre.

\section{Yields}

On the basis of information provided by the growers, average marketable yields are about 9,847 pounds per acre per year.

\section{Mamey Sapote Prices}

The average F.O.B. (Homestead) price for mamey sapote is estimated at $\$ 1.17$ per pound. This estimate is calculated from the prices received by growers from packinghouses during 2016.

\section{Irrigation}

Adequate water supply is critical during flowering, fruit set, and early fruit development. Mature trees should be watered once or twice per week with 1 inch $(2.5 \mathrm{~cm})$ of water during periods of insufficient rainfall (Balerdi et al. 2008). Average irrigation expenses comprised of fuel/electricity costs are estimated at \$94/acre/year.

\section{Fertilization}

Conventional fertilizer practices include applications of 8-3-9 (NPK) or a similar fertilizer material, foliar-applied micronutrients (e.g., manganese, zinc, and boron), and soildrench applications of chelated iron. Average fertilization costs (materials only) are estimated at \$95/acre/year.

\section{Pest Management}

Few insects and diseases attack mamey sapote, so the level of damage does not always require control (Mossler and Crane 2013). The most common pests include leafhoppers (Order Hemiptera) feeding on immature leaves, Cuban May beetle (Phyllophaga bruneri) feeding on the leaves during the summer months, sugarcane rootstalk borer (Diaprepes abbreviatus), and various scales such as the white peach scale (Pseudaulacaspis pentagona), philephedra scale (Philephedra sp.), and wax scales (Ceroplastes sp.). Mamey sapote diseases include anthracnose (Penz), which may damage flowers and young leaves; red alga (Cephaleuros virescens Kunze), which attacks twigs and limbs; and root diseases (Rhizoctonia sp., Pythium splendens) (Balerdi et al. 2008). Average agrochemical costs (materials only) include herbicides ( $\$ 87 /$ acre/year), insecticides ( $\$ 137 /$ acre/year), and fungicides (\$123/acre/year).

\section{Labor Costs}

These include agricultural input application costs (e.g., fertilizers and agrochemicals) and cultural operation costs (e.g., irrigation management and repair, pruning, and mowing vines). Labor costs are estimated at \$569/acre/year. 


\section{Interest on Operating Capital}

This is the cost of borrowing money or the opportunity cost for using equity. A rate of $5 \%$ is used in the present analysis.

\section{Fixed Overhead Costs}

These represent fixed expenses to operate a farm. The costs include cash overhead costs (insurance and taxes), noncash overhead costs (land rent) and other overhead costs (machinery depreciation, interest, electricity, telephone, computer, and other office expenses). Fixed overhead costs are estimated at $\$ 1,112 /$ acre/year.

\section{Harvesting and Marketing Costs}

Harvesting mamey sapote is a very labor-intensive process because each fruit must be individually tested for maturity before harvesting. For commercial purposes, the fruit is considered horticulturally mature for harvest when the pulp has a reddish color. The cost of picking, packing, and sales is estimated at $\$ 1,454 /$ acre/year ( $\$ 0.15$ per pound).

The total expenses and returns associated with an orchard in full production includes operating costs, fixed costs, and harvesting and marketing costs (Table 1). The various components include operating costs, fixed overhead costs, and harvesting and marketing costs.

- Operating Costs or variable costs total $\$ 1,160 /$ acre/year (about $\$ 0.12 / \mathrm{lb}$.), representing $31 \%$ of total cost. The major cost components within this category are hired labor (49\%), insecticides (11\%), and fungicides (10\%).

- Fixed Overhead Costs include insurance, property taxes, other overhead charges (electricity, insurance, telephone, etc.), and land rental. Although growers already own the land, the land rental charge of $\$ 550 /$ acre/year reflects the opportunity cost of the land. Fixed costs are estimated at $\$ 1,112 /$ acre/year.

- Harvesting and Marketing Costs are estimated at $\$ 1,454 /$ acre/year ( $\$ 0.15 / \mathrm{lb}$.), representing 38\% of total cost of production. Harvesting the fruit is a timeconsuming process because each fruit must be inspected for maturity before harvesting.

The total cost structure for mamey sapote production and the respective share of its components are shown in Figure 4. Harvest and marketing costs are the major cost drivers, accounting for $38 \%$ of total cost, followed by operating costs (variable costs for pruning, fertilization, and pest control) at $31 \%$, fixed overhead costs at $29 \%$, and interest on capital at $2 \%$ of total cost.
Total costs structure

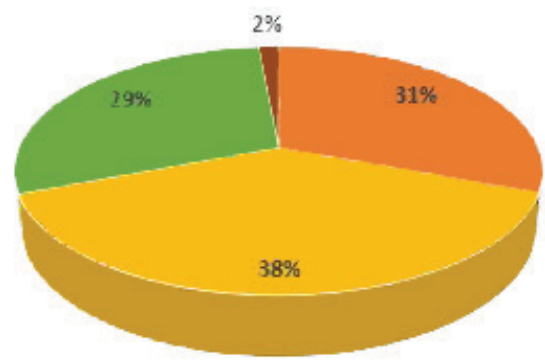

- Operating costs - Harvest and marketing costs - Fixed costs = Interest on capital Figure 4. Total cost structure.

\section{Returns and Profitability Analysis}

Based on the information provided by the growers, the average marketable yield is about 9,847 pounds/acre/year. Assuming a planting density of 116 trees/acre, per-tree yield is about 90 pounds.

Using the average F.O.B. Homestead price of \$1.17/ pound, total revenue is $\$ 11,521$ /acre/year. Subtracting total variable cost (total operating cost plus harvesting and marketing cost) from total revenue results in a gross margin $(\$ 11,521-\$ 2,614)$ of $\$ 8,907 /$ acre/year. The gross margin provides an indication of short-term profitability. A positive gross margin implies that all variable costs have been covered and there are additional funds remaining to cover some or all of the fixed overhead costs. Following this approach implies a return of $\$ 0.90$ /pound compared to other south Florida crops such as avocado (\$0.15/pound). Note that profitability based on the gross margin is not a true reflection of the long-term profitability of the business.

Many growers are only concerned with the gross margin. However, a more realistic approach is to calculate the net return, which also considers the fixed overhead costs. The net return is $\$ 7,795 /$ acre, or $\$ 0.79 /$ pound; this is still attractive compared to the returns obtained from other tropical fruits in the area.

\section{Sensitivity Analysis}

A sensitivity analysis of net returns to the grower on a peracre basis demonstrates how profitability of the operation may change with changes in yield and prices (Table 2). In a best-case scenario where both price and yield are assumed to increase by $10 \%$, net return per acre would increase from $\$ 7,795$ to $\$ 10,247$. In a worst-case scenario where both price and yield decline by $10 \%$, net return per acre would decrease from $\$ 7,795$ to $\$ 5,579$ per acre. Other combinations of changes in prices and yields and their impact on net return per acre are shown in Table 2. However, it should 
be noted that at the industry level, a noticeable increase in production usually results in a decrease in the price re-

ceived by the growers. A similar analysis conducted on the basis of gross margin (gross profit) may be interpreted in a similar manner as in Table 2, noting that this is with respect to gross profit, which ignores the fixed cost estimates (Table $3)$.

\section{Conclusions}

Our estimate of total annual production cost for mamey sapote in south Florida is $\$ 3,726 /$ acre, or about $\$ 0.38$ / pound. A gross revenue of $\$ 11,521 /$ acre ( $\$ 1.17 /$ pound) results on a net return to the grower of about $\$ 7,795 /$ acre, or $\$ .79 /$ pound, which makes this tropical fruit crop an interesting option. It is important to point out that the information presented here refers to established groves. Assessing the profitability of establishing a new mamey sapote grove includes additional budget considerations: land acquisition, establishment of the grove, and financing for capital investment are all added costs. Also, the exotic fruit market is considered a niche market, with oversupply resulting in a precipitous fall in prices. As a precaution, potential investors should proceed with care before starting any new enterprises.

\section{References}

Balerdi, C.F., J.H. Crane, and I. Maguire. 2008. Mamey Sapote Growing in the Florida Home Landscape. FC-30. Gainesville, FL: University of Florida Institute of Food and Agricultural Sciences. http://edis.ifas.ufl.edu/MG331

Mossler, A.M., and J.H. Crane. 2013. Florida Crop/Pest Management Profile: Mamey Sapote and Sapodilla. Gainesville, FL: University of Florida Institute of Food and Agricultural Sciences. http://www.growables.org/information/TropicalFruit/documents/FloridaCropPestManagementMameySapoteSapodilla.pdf

Goenaga, R.J., and D.A. Jenkins. 2012. "Yield and fruit quality traits of mamey sapote cultivars grown at two locations in Puerto Rico." HortTechnology 22:263-267.

Morton, J. 1987. Fruits of Warm Climates. https://www.hort. purdue.edu/newcrop/morton/mamey.html

Pantin, D. 1991. “Pantin's mamey." Tropical Fruit World 2(1):12-17. 
Table 1. Costs and returns associated with an established mamey sapote orchard in south Florida.

$\begin{array}{lccc}\text { Item } & \begin{array}{c}\text { Quantity } \\ \text { (pounds) }\end{array} & \begin{array}{c}\text { Value per acre } \\ \text { (\$/acre/year) }\end{array} & \begin{array}{c}\text { Value per pound } \\ \text { (\$/pound) }\end{array}\end{array}$

\section{Revenue}

Marketable Yield (pounds/acre) 9,847

F.O.B. Homestead Price

11,521

1.17

Total Revenue

\section{Operating Costs}

Irrigation 94

Fertilizer 95

Herbicide 87

Insecticide 137

Fungicide

123

Labor cost

569

Interest on Operating Capital (5\%)

55

Total Operating Cost

1,160

0.12

Fixed Overhead Costs

Cash Overhead:

$\begin{array}{ll}\text { Insurance } & 100 \\ \text { Taxes } & 100\end{array}$

Non-Cash Overhead:

Land Rent 550

Other Overhead 362

\begin{tabular}{lll} 
Total Fixed Overhead Cost & 1,112 & 0.11 \\
\hline Total Pre-Harvest Cost & 2,272 & 0.23 \\
\hline Harvest and Marketing Costs & \\
Picking, Packing, and Sales Cost & 1,454 & 0.15 \\
Total Harvest and Marketing Cost & 1,454 & 0.15 \\
\hline Total Cost & 3,726 & 0.38 \\
Gross Margin & 8,907 & 0.90 \\
Estimated Net Return & 7,795 & 0.79 \\
\hline
\end{tabular}


Table 2. Sensitivity analysis, net returns per acre.

\begin{tabular}{|c|c|c|c|r|r|r|}
\hline \multicolumn{2}{|c|}{ Yield (pounds/acre) } & \multicolumn{5}{|c|}{ Wholesale Price (dollars/pound) } \\
\cline { 3 - 6 } & & 1.05 & 1.11 & 1.17 & 1.23 \\
\cline { 3 - 6 } & & $(-10 \%)$ & $(-5 \%)$ & (base) & $(+5 \%)$ \\
\hline 8,862 & $(-10 \%)$ & 5,579 & 6,111 & 6,643 & 7,174 \\
\hline 9,355 & $(-5 \%)$ & 6,097 & 6,658 & 7,219 & 7,781 \\
\hline 9,847 & (base) & 6,613 & 7,204 & 7,795 & 8,386 \\
\hline 10,339 & $(+5 \%)$ & 7,130 & 7,750 & 8,371 & 8,991 \\
\hline 10,832 & $(+10 \%)$ & 7,648 & 8,298 & 8,948 & 8,611 \\
\hline
\end{tabular}

Table 3. Sensitivity analysis, gross margin per acre.

\begin{tabular}{|c|c|c|c|c|c|c|}
\hline \multicolumn{2}{|c|}{ Yield (pounds/acre) } & \multicolumn{5}{|c|}{ Wholesale Price (dollars/pound) } \\
\cline { 3 - 6 } & & 1.05 & 1.11 & 1.17 & 1.23 \\
\hline & & $(-10 \%)$ & $(-5 \%)$ & (base) & $(+5 \%)$ \\
\hline 8,862 & $(-10 \%)$ & 6,692 & 7,223 & 7,755 & 8,287 \\
\hline 9,355 & $(-5 \%)$ & 7,209 & 7,771 & 8,332 & 8,893 \\
\hline 9,847 & (base) & 7,726 & 8,317 & 8,907 & 9,498 \\
\hline 10,339 & $(+5 \%)$ & 8,242 & 8,863 & 9,483 & 10,103 & 10,089 \\
\hline 10,832 & $(+10 \%)$ & 8,760 & 9,410 & 10,060 & 10,060 \\
\hline
\end{tabular}

